
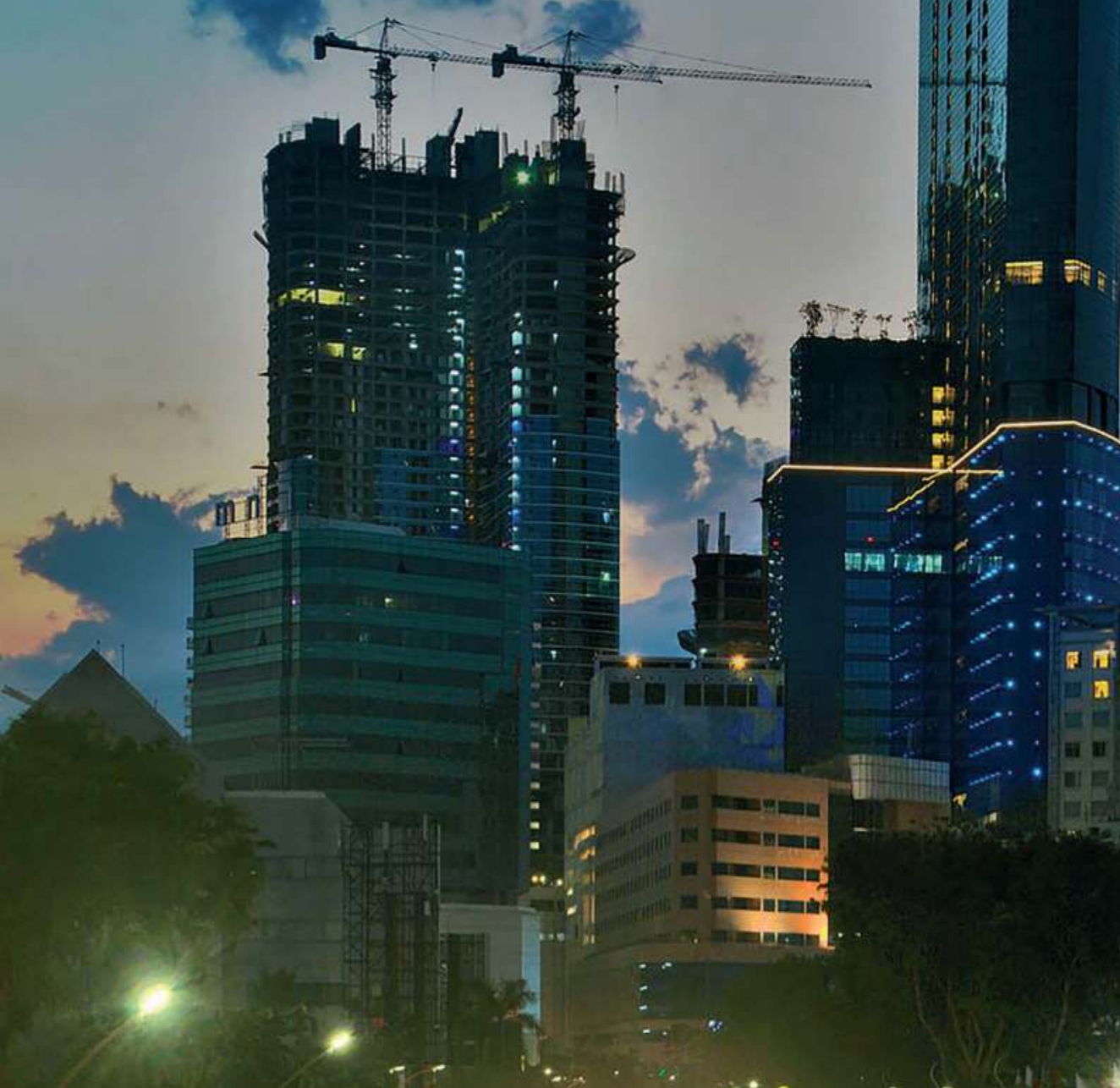

\section{Editors}

Badri Munir Sukoco

Rahmat Heru Setianto Nidya Ayu Arina Ade Gafar Abdullah Asep Bayu Nandiyanto Ratih Hurriyati

\section{Increasing Management Relevance \\ and}

\section{CPD \\ CERTIFIED

(ci. C) CRC Press

A BALKEMA BOOK 
PROCEEDINGS OF THE $2^{\text {ND }}$ GLOBAL CONFERENCE ON BUSINESS, MANAGEMENT AND ENTREPRENEURSHIP (GC-BME 2017), AUGUST 9, 2017, UNIVERSITAS AIRLANGGA, SURABAYA, INDONESIA

\section{Increasing Management Relevance and Competitiveness}

Editors

Badri Munir Sukoco, Rahmat Heru Setianto \& Nidya Ayu Arina Universitas Airlangga, Indonesia

Ade Gafar Abdullah, Asep Bayu Nandiyanto \& Ratih Hurriyati Universitas Pendidikan, Indonesia

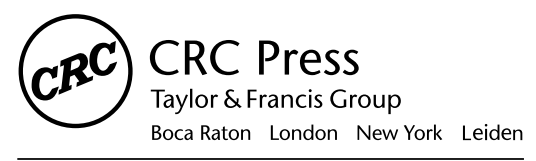

CRC Press is an imprint of the

Taylor \& Francis Group, an informa business

A BALKEMA BOOK 
CRC Press/Balkema is an imprint of the Taylor \& Francis Group, an informa business

(C) 2018 Taylor \& Francis Group, London, UK

Typeset by V Publishing Solutions Pvt Ltd., Chennai, India Printed and bound in Great Britain by CPI Group (UK) Ltd, Croydon, CR0 4YY

All rights reserved. No part of this publication or the information contained herein may be reproduced, stored in a retrieval system, or transmitted in any form or by any means, electronic, mechanical, by photocopying, recording or otherwise, without written prior permission from the publisher.

Although all care is taken to ensure integrity and the quality of this publication and the information herein, no responsibility is assumed by the publishers nor the author for any damage to the property or persons as a result of operation or use of this publication and/or the information contained herein.

Published by: CRC Press/Balkema

Schipholweg 107C, 2316 XC Leiden, The Netherlands

e-mail: Pub.NL@taylorandfrancis.com

www.crcpress.com - www.taylorandfrancis.com

ISBN: 978-0-8153-7455-8 (Hbk)

ISBN: 978-1-351-24189-2 (eBook) 


\section{Table of contents}

Preface $\quad$ xi

$\begin{array}{lc}\text { Acknowledgements } & \text { xiii }\end{array}$

$\begin{array}{ll}\text { Organizing committees } & \mathrm{XV}\end{array}$

Strategic management, entrepreneurship and contemporary issues

Governance of financial intangible success factors: An option in building business resilience and sustainability

P. Sugito

The influences of the alliance learning process and entrepreneurial orientation on the strategic alliance performance of Indonesian construction companies R. Handayani \& R. Dyah Kusumastuti

Assessing necessity and opportunity-based entrepreneurship: An analysis of demographic characteristics, propensity for new ventures and entrepreneurial motivation (a study of labor forces and entrepreneurs in Padang, Indonesia)

H. Rahman \& D. Lesmana

Critical assessment on zakat management: Zakat scorecard model

T. Widiastuti, S. Herianingrum \& I. Mawardi

Investigating entrepreneurial orientation impact on project performance in highly regulated industry: A case of renewable power industry in Indonesia

F.A. Firman, R.D. Kusumastuti, H.T. Kurniawan \& I.M. Ruky

How to survive in the modern era: Integrated local entrepreneurs, the traditional market and the modern store

P.P.D. Astuti, Y. Setyowati \& A.A.G.S. Utama

xi iii

XV

The influence of Islamic service quality toward bank customer loyalty and satisfaction of

BRISyariah Surabaya

M.Q. Fauzi, S. Herianingrum, T. Widiastuti \& R. P. Putra

Management accounting practices in micro enterprises in the Sleman Regency, Daerah

Istimewa Yogyakarta

A.C. Laksmi \& A.P. Putra

The power of finance: The dynamics of female entrepreneurs in fulfilling their financial needs

M.R. Rita, S. Wahyudi \& H. Muharam

Entrepreneurial orientation in a family business group: The role of the corporate center and its effect on business unit performance

O. Pendrian, K.A. Karnen, R. Rachmawati \& R.D. Kusumastuti

Developing entrepreneurship for the performing arts community through an art incubation model

J. Masunah \& R. Milyartini

Capability to contest on market performance

61

B. M. Sukoco \& R. R. Maulana 
The influence of the socio-economic status of parents toward entrepreneurial attitudes H. Mulyadi, M. Arief Ramdhany \& S. Sulastri

Analysis of the factors affecting the elected mode of transportation for workers using an analytical hierarchy process

E. Mahpudin \& H. Sulistiyo

71

75

Multidimensional approach for assessing service quality in the service industry

Y.D. Lestari

The influence of entrepreneurship orientation and management capability on performance of small and medium enterprises in Bogor

A. Setyo Pranowo, H. Hari Mulyadi, Z. Musannip Efendi Siregar \&

Y. Hendayana

The influence of family factors on expatriate performance

N. Kartika

Is firm size an important determinant for firms in establishing political connections?

N.N. Amorita, D. Agustia \& I. Harymawan

Integration of corporate social responsibility and resource based theory to create

and capture value

N. Nandang \& H. Mulyadi

Organizational behavior, leadership and human resources management

Superior performance model of human resources

T. Yuniarsih, Disman \& M.D. Sugiharto

The impact of fiscal decentralization on economic growth and manpower absorbed at districts/cities in South Kalimantan Province

Muzdalifah \& R. Purwono

Work-family conflict and satisfactions: A job demand-resources model perspective

J. Sulistiawan

Building employee engagement through transformational leadership, psychological empowerment and affective commitment

P. Yulianti \& N. Hamidah

The impact of transformational leadership, learning organization and job autonomy on creative self-efficacy

I. B. G. A. Permana \& W. Astiti

Enhancing commitment to organizational change initiative and performance outcomes N.A. Arina \& P. Yulianti

The influence of Perception of Usefulness (PoU) and Perceived Ease of Use (PEU) on the perception of information system performance

F. Sayekti \& L.E. Wijayanti

Knowledge sharing benefits: The contingency effects of environmental contexts

A. Qomariyah

The antecedents of entrepreneurial intentions in students of Airlangga university

(A study of student participants in WEBS in the faculty of economics and business)

P. Yulianti \& I. G.N.W.H. Saputra

Effect of proactive personality and Organizational Support for Career Development (OSCD) on career satisfaction and job performance

V. Octia \& D. Ratmawati

The effects of transformational and transactional leadership on work performance of middle-level leaders with organizational commitment as mediator: A study of state-owned company, Pelabuhan Indonesia III Inc.

A. Eliyana, S. Maarif \& R.J. Sunarsono 
Transformational leadership style, team performance and team job satisfaction:

Mediation by levels of cognitive trust and collective efficacy

P. Yulianti \& R. Sanjaya

The impact of self-efficacy and perceived organizational support on operational managers' readiness to change

H. Prima \& A. Eliyana

\section{Marketing management}

Factors affecting customer retention in a priority banking program

I.R. Aliyah, S. Soebandhi \& A. Baktiono

The impact of messages assertiveness on compliance with perceived importance as a moderation variable on the anti-cigarette campaign in Surabaya

Kristiningsih, R.S. Wuryaningrum \& A. Trimarjono

Demographic variables and environmentally friendly behavior in a developing country

T. Handriana

Antecedents and consequences of ongoing search information

D. T. Firmansyah \& D. Mardhiyah

Role of negative brand name perception and religiosity on brand attitude

S. Gunawan \& R.T. Ratnasari

The effects of good/bad news on consumer responses toward higher education

G.C. Premananto \& M.H. Hanafiah

Examining leadership style and advertising evaluation on employees'

customer focus

R.A. Aisyah \& N.A. Arina

The effect of airline sale promotion types on consumers' attitudes toward brand and purchase intentions

M. Kurniawati

The influence of celebgrams, e-WOM, and pictures on impulse buying

Hartini, Sri \& Uswatun

Value propositions of supermarkets

R. Rinawati

Empirical study of perceived quality information and perceived information security impact on online purchasing in Indonesia

L. Lisnawati, L.A. Wibowo \& P. Andi

Measuring religiosity and its effects on attitude and intention to wear a hijab:

Revalidating the scale

H.A. Wibowo \& M.R. Masitoh

\section{Management and economics education}

Communication skills of accountants and managers in Indonesia

Y.L. Rudianto \& A.R. Sridadi

Factors knowledge management and the work motivation of lecturers

Rino

The role of talent management in student performance in higher education

D. Purwaningsih

Strategy to build universities

P. Dewi Dirgantari, B. Widjajanta \& L. Lisnawati

Factors affecting the improvement of students' Grade Point Average (GPA)

A.B. Santoso, E.C.M. Simatupang \& R.H. Sofyandi 


\title{
The influence of celebgrams, e-WOM, and pictures on impulse buying
}

\author{
Hartini, Sri \& Uswatun \\ Universitas Airlangga, Surabaya, Indonesia
}

\begin{abstract}
In this research, the author proposes that social media has an effect on consumer behavior. This study aims to examine the relationship between celebgrams (celebrities on Instagram), electronic Word of Mouth (e-WOM), and pictures on impulse buying. A sample was obtained through purposive sampling and 116 samples used. The results showed that celebgrams have a positive, statistically significant influence on impulse buying. Neither pictures nor e-WOM had a significant influence on impulse buying.
\end{abstract}

Keywords: celebgram, e-WOM, pictures, impulse buying

\section{INTRODUCTION}

The variety of emerging adult social media also affects the mechanism of selling-purchasing in more diverse forms as well. Whereas in the 1960s buyers and sellers had to be able to meet physically to conduct transactions, in 2016 sellers and buyers no longer have to do this.

By utilizing the facilities provided by the Internet and social media the seller can promote to unlimited market segments, the cost allocated to the promotion budget can be minimized, and relatively small capital is required, along with a trimmed distribution chain. The inventory cost can be eliminated, which will, of course, lower the price. Principal sales can attract consumer interest so that the potential to achieve as much profit as possible will be easily achieved.

Individuals and groups have begun to use social media as a medium to support the delivery of messages. Businesses today have social media accounts like Twitter, Facebook, Instagram and others to introduce products or communicate with their customers (Purnomo, 2015). A social media with the main focus of visual content in the form of photos, and which has become one of the most popular media in Indonesia, is Instagram (maxmanroe, 2014).

Instagram can load the image of the product with complete and excellent image quality. Thousands and even up to millions of images can be stored that are at once accessible to both sellers and buyers. In social media, the seller can provide as much information as possible about the products offered. The information submitted is precise, accurate and has a fixed standard and it aims to provide uniform information about the product and thus reduce misunderstanding of product information to consumers.
Sellers no longer have to pay sales force personnel to simply explain product information or serve to help the payment process, especially given the fact, for various reasons, that the sales force is not always best placed to deal with consumers. Sellers and buyers do not need to conduct meetings for the transfer of knowledge, but information can be accessed anywhere at any time as long as there is an Internet connection, so as not to take up time for either sellers or buyers.

Surfing on the Internet is analogous to walking around the mall while looking at stores without buying anything. Online shopping can form a rational buying behavior. This is supported by the fact that the Internet has the characteristics of efficiency and a variety of information enabling consumers to make price comparisons as well as obtain other information about a product.

From here arose the expectation that consumers use logic as well as grounded reasons when making a purchase. However, the fact is that not all consumers act rationally and logically when transacting or making online purchases. Therefore, the term irrational buying or unregulated buying was devised. According to LaRose (2002), unregulated buying consists of impulse buying, compulsive buying, and addictive buying. These three types of purchase are a form of deviation from consumer behavior in the context of the shopping environment.

\section{THEORETICAL FRAMEWORK AND HYPOTHESIS}

Lovelock (2008) explains that word of mouth or testimony can consist of comments or recommendations distributed by the customer, based on their experience, which have a strong influence on the 
decision-making of others. Based on the above opinion, it can be concluded that testimony is a form of marketing that tends to include communication that can be delivered directly to provide information, and promote, or recommend a product or service.

\section{H1: Electronic Word of Mouth (e-WOM) posi-} tively affects consumer impulse buying.

A 'celebgram' can be interpreted as a celebrity endorser on Instagram social media. According to Shimp (2002), an 'ad advocate', also known as an 'ad star', is someone who supports an advertised product. An endorser is a particular icon or figure who is often also referred to as a direct source to deliver a message and/or demonstrate a product or service through promotional activities aimed at supporting the effectiveness of the delivery of the product messages (Belch \& Belch, 2004, p. 168) endorsers are divided into two types: typical-person endorsers are ordinary people not well-known who are used to advertise a product, whereas a celebrity endorser is a famous person used to support an advertisement. Both types of endorsers have the same attributes and characteristics.

\section{$\mathrm{H}$ 2: Celebgrams positively affect consumer impulse buying.}

According to Sadiman (2006, pp. 28-29), images are part of visual graphics media as well as other media. Graphics media aims to channel messages from sources to message recipients through visual channels. Messages to be delivered are poured into visual communication symbols. These symbols need to be understood correctly as regards their meaning so that the message delivery process can be successful and efficient.

H3: Pictures positively affect consumer impulse buying.

\section{RESEARCH METHOD}

The population in this study is comprised of people who have an Instagram account and the study uses a purposive sampling method, whereby not all members of the population have the same opportunity to become a member of the sample. The population of individuals is virtually unlimited in number. Purposive sampling is a sample determination technique that enables anyone found and considered appropriate as a sample of a study to be a data source (Aaker et al., 1996). The sample size was 116 people who have an Instagram account and had never made a purchase of fashion products through the social medium of Instagram.

\subsection{Measurement}

Word of mouth or testimony is a comment or recommendation that a customer disseminates based on their own experience, indicators are number of likes and number of positive comments on the celebgram page uploader (Shimp, 2002). Picture images are visual graphics media that aim to deliver messages from sources to the message recipients (Sadiman et al., 2003, pp. 28-29). Solomon (2004, p. 408) describes impulse purchases as unplanned purchases which arise when one feels a sudden impulse buying. The data analysis technique used in this study is multiple linear regression analysis in statistics, a mathematical formula that shows the relationship between one or more variables whose value is known and a variable whose value is not known.

\section{RESULT AND DISCUSSION}

The research respondents consisted of mostly females $(70 \%)$, while male respondents comprised $30 \%$. The percentage of respondents aged between 20 and 24 years was 51\%; those aged 24-29 was $21 \%$; aged $30-34$ was $11 \%$; aged $34-39$ was $10 \%$; aged over 39 was $7 \%$.

The educational background of respondents consisted of: postgraduate (S2) at 8\%; undergraduate education (S1) at $41 \%$; diploma education or equivalent at $30 \%$; respondents with high school education at $21 \%$. In terms of employment, $42 \%$ of respondents were students, while respondents with jobs as private employees accounted for $25 \%$, respondents with entrepreneur jobs totaled $14 \%$, and respondents with a job as a civil servant comprised 5\%. Respondents having jobs other than those mentioned accounted for $13 \%$. Those with an income between Rp. 2,500,000 and Rp. 4,990,000 accounted for $31 \%$; respondents with an income between Rp. 1,000,000 and Rp. 2,490,0000 numbered $20 \%$; respondents with a maximum income of $1,000,000$, and those with an income between Rp. 5,000,000 and Rp. 6,990,000 each accounted for $18 \%$; respondents with an income between $\mathrm{Rp}$. 7,000,000 and Rp. 9,990,000 totaled $8 \%$, while 5\% of respondents had an income greater than $\mathrm{Rp}$. $10,000,000$.

Test results with SPSS used the 0.05 significance limit (i.e. if the significance value is smaller than the $5 \%$ level, it means the null hypothesis, $\mathrm{H}_{0}$, is rejected and the alternative hypothesis, $\mathrm{H}_{\mathrm{A}}$, accepted). Test results obtained for testimonial variable t test equal to -1.168 with significance level 0.245 , by using the 0.05 significance limit, the first hypothesis is rejected. This means testimony on Instagram does not affect consumer impulse buying. However, the 
second hypothesis is accepted. Test results show that celebgram obtained t test equal to 5,538 with level of significance, this means that if a better known celebgram is on, it will affect consumer impulse buying. The third hypothesis is rejected. This means a good picture of the product on Instagram has no effect on impulse buying.

Celebgram is found to significantly influence the impulse buying of consumers while the other independent variables of testimony and images are found to have no significant effect on impulse buying. This happens because the consumer familiar with the purchase online, so they understand that testimony is a marketing strategy, testimony made by the company. Consumers experienced that the product sent not in accordance with the image shown in on line.

The phenomenon of engineered testimony by producers or marketers is being used more frequently, both in terms of quantity and content, making consumers less trusting of the accuracy and validity of testimony submitted by the manufacturer.

The discovery of a commentary on the incompatibility of images with products received by consumers also led to high levels of consumer distrust of the images listed on Instagram. This was also supported by the sophistication of editing technology and camera resolution to improve image quality in terms of lighting, color combinations, and so on. Consequently, consumers feel unsure, and ultimately do not encourage other consumers to do impulse buying.

Whereas in the variable of the known celebgram, the result is significant, as a result of the tendency of the consumer to idolize the celebgram so that anything that is delivered by the celebgram is considered correct. Based on the definition of impulse buying described in the previous chapter, meaning that purchase is irrational or without intent, Consumers who feel positive about a particular celebgram, this will make the celebgram a reference in impulsively choosing a product.

\section{CONCLUSION}

Based on research about the influence of e-WOM, celebgrams, and pictures of fashion products on Instagram on impulse buying consumers, the following conclusions are drawn: the results of multiple linear regression and $t$-tests on the respondents' answers show that there is only one regression coefficient signified as positive and significant: celebgrams.

This means that celebgrams have a positive and significant influence on consumer impulse buying. This means the better the celebgram, the more positive and significant the impact on consumer impulse buying. The image/picture has a negative and not significant influence on consumer impulse buying. This means that any image on Instagram will not affect consumer impulse buying.

\section{REFERENCES}

Aaker, D., Batra, R. \& Myers, J.G. (1996). Advertising management (5th ed.). Englewood Cliffs, NJ: Prentice Hall.

Ali, H. (2010). Marketing dari Mulut ke Mulut [Word of mouth marketing]. Yogyakarta, Indonesia: Media Presindo.

Belch, George E. Belch, Michael, A. (2009). Advertising and Promotion: An Integrated Marketing Communication Perpectiv. 8th Edition. New York: Mc Grow-Hill.

Cobb, C.J. \& Hoyer, W.D. (1986). A planned versus impulse purchase behaviour. Journal of Retailing, 62, 67-81.

Hu, Y., Manikonda, L. \& Kambhampati, S. (2014). What we Instagram: A first analysis of Instagram photocontent and user types. In Proceedings of the 8th International Conference on Weblogs and Social Media, ICWSM 2014 (pp. 595-598). Palo Alto, CA: The AAAI Press.

Larose, Robert; Eastin Mathew, Is Online Buying Out of Control? Electronic Commerce and Consumer SelfRegulation, Journal of Broadcasting \& Electronic Media Volume 46, 2002 - Issue 4.

Lovelock, C. \& Wright, L.K. (2011). Service marketing, people, technology, strategy. Upper Saddle River, NJ: Prentice Hall.

Maxmanroe (2014). 7 Fakta Unik Instagram yang Perlu Diketahui oleh Internet Marketer.

Mayfield, A. (2008). What is social media. ICrossing.

Muruganantham, G. \& Bhakat, R.S. (2013). A review of impulse buying behaviour. International Journal of Marketing Studies, 5(3), 149-160.

Nielsen, A.C. (2007). Survey of consumer behaviour and perception toward modern retail and traditional trade channels. Jakarta, Indonesia: Departemen Perdagangan Indonesia.

Purnomo, Wahyu D. (2015). Apa Itu Sosial Media Marketing? http://semseomanagement.com/apa-itu-socialmedia-marketing/.

Rook, D. \& Fisher, J.R. (1995). Normative influences on impulsive buying behaviour. Journal of Consumer Research, 22(3), 305-313.

Sadiman, 2006, Media Pendidikan, pengertian, pengembangan, dan Pemanfaatanya Jakarta: Pustekom. Dikbud, PT Raja Grafindo.

Shimp, Terence. (2002). Periklanan Promosi. Erlangga. Jakarta.

Shoham, A. \& Brencis, M.M. (2003). Compulsive buying behaviour. Journal of Marketing Research, 20, $127-138$

Solomon (2004), Consumer behavior, buying, having and being, Amazon.com.

Stern, H. (1962). The significance of impulse buying today. Journal of Marketing, 26(2), 59-62. 